\title{
ApPlication OF ARTiCLE 6 OF THE EUROPEAN CONVENTION OF HUMAN Rights IN ENFORCEMENT PROCEEDINGS
}

Accepted

10. 11.2020

Revised

15. 01.2021

Published

30. 06. 2021

Keywords

enforcement

proceedings,

human

rights,

right to

a fair

trial,

arbitration,

effective

legal

defence

\section{DALIA VIŠINSKYTĖ, MYKOLAS KIRKUTIS,}

\author{
REMIGIJUS JOKUBAUSKAS \& VIGINTAS VIŠINSKIS \\ Mykolas Romeris University in Vilnius, Vilnius, Lithuania \\ E-mail: dalia.visinskyte@mids.ch,mkirkutis@gmail.com, \\ remigijus@jokubauskas.org,vigvis@gmail.com \\ CORRESPONDING AUTHOR \\ dalia.visinskyte@mids.ch
}

\begin{abstract}
The application of procedural guarantees of the right to a fair trial is significant for effective legal defence. Certain element of the right to a fair trial are applicable in enforcement proceedings, such the requirement for reasonable length of enforcement proceedings, cooperation between the parties, the principle of adversarial proceedings. Since enforcement proceedings are an integral part of litigation in the court, states may be liable for a failure to ensure effective enforcement proceedings.
\end{abstract}




\section{$1 \quad$ Introduction}

Enforcement proceedings form an integral part of the legal system. However, the position of enforcement proceedings in the legal system is still debatable and raises serious questions regarding the application of human rights in enforcement proceedings. What standards of human rights protection are applicable in enforcement proceedings? Are the same legal protection standards applicable in enforcement proceedings as well as in the court proceedings?

The first question is whether enforcement proceedings fall under the scope of the right to a fair trial. If the answer to the first question is in the affirmative, then the second question becomes to what extent the guarantees of Article 6 of the Convention for the Protection of Human Rights and Fundamental Freedoms (hereinafter: the Convention) is applicable in enforcement proceedings? Third, are the Contracting States liable for enforcement proceedings which do not satisfy the requirements of Article 6 of the Convention? Fourth, is Article 6 of the Convention applicable for enforcement of arbitral awards? This article discusses these questions.

The application of Article 6 of the Convention is intertwined with the application of the regulations of the European Union civil procedure which regulate, at least to a certain, extent cross-border enforcement proceedings. Article 47 of the Charter of Fundamental Rights of the European Union establishes that everyone is entitled to a fair and public hearing within a reasonable time by an independent and impartial tribunal previously established by law. Also, clear references to the protection of the right to a fair trial are made not only in Recital 38 of the Regulation (EU) No. 1215/2012 of the European Parliament and of the Council of 12 December 2012 on jurisdiction and the recognition and enforcement of judgments in civil and commercial matters (Regulation 1215/2012) ${ }^{1}$, but also in Recital 44 of the Regulation (EU) No 655/2014 of the European Parliament and of the Council of 15 May 2014 establishing a European Account Preservation Order procedure to facilitate cross-border debt recovery in civil and commercial matters. ${ }^{2}$ Therefore, the analysis of the problems regarding the application of Article 6 of the Convention in

1 OJ L 351, 20. 12. 2012.

2 OJ L 189, 14. 04. 2014. 
enforcement proceedings is closely linked with the application of the EU regulations on cross-border civil procedure.

\section{The position of enforcement proceedings}

The defence of legal rights does not always end in the court. If the losing party fails to comply with the judgment voluntarily, the legal system provides coercive enforcement measures to ensure that the judgment is executed. Nevertheless, this fundamental requirement raises a dilemma. What is the nature and position of enforcement proceedings in the system of law? Should it be regarded as a constituent element of civil proceedings; an independent field of law; or hybrid proceedings combining both private (civil) and public (administrative) aspects?

During the codification of laws in Europe in the nineteenth century, enforcement proceedings were understood as a natural continuation of adjudication. Later, the idea that enforcement is a part of public (administrative) law emerged (Kerameus, 1997: p. 272). This problem of the nature of enforcement proceedings has not vanished and different authors support different approaches. Some authors suggest that enforcement proceedings in the legal system can be understood as i) part of civil proceedings, ii) part of administrative law or administrative proceedings, iii) an independent branch of law (Валеев, 2008: p. 14). Such distinctions are justified based on the goals and nature of the regulation of enforcement proceedings, which synthesize legal norms which combine both private and public interests. For instance, legal scholars in Lithuania claim that enforcement proceedings are part of civil proceedings due to the fact regulations governing both advance similar goals and objects (Stauskiene, 2007: p. 76). Moreover, one distinct approach has been chosen in the legal regulation of enforcement proceedings in different civil law countries. Enforcement proceedings are regulated by the codes of civil procedure in Lithuania, Latvia, Poland, Germany. However, in other countries, for instance Estonia (Code of Enforcement Procedure (Tätemenetluse seadustik)), France (Civil Enforcement Proceedings Code (Code des procédures civiles d'exécution)), Slovenia (Enforcement and Securing of Civil Claims Act (Zakon o izvrsbi in zavarovanju)), and Sweden (Enforcement Code (Utsökningsbalken)), enforcement proceedings are regulated by the separate laws. These variations suggest that in such countries, enforcement proceedings may be separated from the civil proceedings and serve as a distinct branch of law. Such differences in legal regulation provides support for the 
proposition that the position of enforcement proceedings in the hierarchy of law is unclear. Nevertheless, it seems that though enforcement proceedings traditionally relied on applications by the creditor to drive forward the proceedings (in the same way as the trial on the merits), greater decision-making power is becoming focused within the court itself in many legal systems (since court officers have better access to information about the debtor and their assets than the typical creditor).

The uncertainty regarding both the nature and role of enforcement proceedings in turn leads to difficulties ensuring the protection of human rights in such proceedings. Noteworthy, the Convention does not use the concept of civil proceedings in Article 6, but civil rights and obligations meaning that it should be determined what constitute civil rights and obligations. This problem was discussed by K. D. Kerameus. He argued that the constitutional guarantee to the access to justice extends beyond ordinary adjudicative procedures to enforcement as well. Also, he aptly claimed that enforcement in many cases intervene into the constitutionally protected area of the right to property which protection in turn requires involvement of the state (Kerameus, 1997: p. 2). This intervention also requires certain involvement of the state to ensure not only the lawful but also the proportionate application of coercive measures. Thus, according to K. D. Kerameus, enforcement proceedings are so intertwined with the litigation phase of court proceedings that they shall not be separated from such proceedings.

The European Court of Human Rights (thereinafter: ECHR) adheres to this notion when it analyses the nature of enforcement proceedings in the context of human rights protection. Noteworthy, the purpose of the Convention at the drafting stage of the documents was to ensure a fair litigation in the court. There is no evidence in the Convention's drafting history that the right to a fair trial should beyond the case hearing in the court to the enforcement proceedings. However, in case Hornsby $v$. Greece, in which state authorities did not take any action to execute a Greek court judgment for five years, the ECHR found that the right to court access would be illusory if a Contracting State's domestic legal system allowed a final, binding judicial decision to remain inoperative to the detriment of one party. Accordingly, the execution of a judgment given by any court of any Member State must therefore be regarded as an integral part of the "trial" for the purposes of Article 6. ${ }^{3}$ Even though

\footnotetext{
${ }^{3}$ ECtHR 19.03.1997, Case Hornsby v. Greece, No. 18357/91, para. 40.
} 
this case concerned enforcement of a judgment rendered in administrative proceedings, given the soundness of its reasoning, its interpretation has been extended to civil cases as well. ${ }^{4}$ Indeed, the court has further expanded this reasoning to the enforcement of foreign decisions. ${ }^{5}$ Also, the court has held that public authorities dot no enforce judgments of their own motion, but they are called upon to lend their assistance since public authorities when the debtor refuses to execute the judgment voluntarily (fr. lorsque le débiteur refuse d'exécuter volontairement une décision de justice). ${ }^{6}$ Similar rationale has been accepted in the Lithuanian case law. The Supreme Court of Lithuania held that the actual enforcement of a judgment is an integral part of a person's right to a fair trial, and situations in which the debtor does not voluntarily comply with enforcing the judgment should not be tolerated in a state governed by the rule of law. ${ }^{7}$

This idea of integral enforcement proceedings has been also affirmed by the further case law of the ECHR and the documents prepared by the Council of Europe. For instance, in 2003 the Council of Europe adopted recommendations in which it stated that the enforcement of a court judgment within a reasonable time is an integral part of the fundamental human right to a fair trial, in accordance with Article 6 of the Convention. ${ }^{8}$ In 2010 the Council of Europe published Opinion No.13 (2010) On the role of judges in the enforcement of judicial decisions, in which it noted that enforcement should be understood as putting into effect judicial decisions and also other judicial or non-judicial enforceable titles. The effective enforcement of a binding judicial decision is a fundamental element of the rule of law. Independence and the right to a fair trial are in vain if the decision is not enforced. The enforcement procedure must be implemented in compliance with fundamental rights and freedoms (Articles 3, 5, 6, 8, 10, 11 of the ECHR, data protection, etc.). ${ }^{9}$

However, the case law of the ECHR does not settle the dilemma of the position of enforcement proceedings in the legal system. It does not, in particular, answer the question whether enforcement proceedings are part of civil proceedings or not.

\footnotetext{
${ }^{4}$ ECtHR 7.04.2005, Case Ǔ̌kureliene and others v. Lithuania, No. 62988/00, para. 31.

${ }^{5}$ ECtHR 29.04.2008, Case McDonald v. France, No. 18648/04.

${ }^{6}$ ECtHR 12.11.2002, Case Döry v. Sweden, No. 28394/95, p. 37-4; ECtHR 03.02.2005, Case Fociac v. Romania, No 2577/02, para. 65 .

${ }^{7}$ The Supreme Court of Lithuania 01.10. 2015, case No. 3K-3-494-701/2015.

${ }^{8}$ Council of Europe Recommendation Rec (2003) 17 of the Committee of Ministers to Member States on Enforcement.

${ }^{9}$ Council of Europe Opinion no.13 (2010), para. 6-8.
} 
Article 6 of the Convention, while it does not specifically regard enforcement proceedings as a part of civil proceedings, nevertheless does require that final legal judgments should be executed (Lautenbach, 2013: p. 146). The requirement for the continuation of legal defence in the court and after litigation strongly suggests that the same level of protection of human rights shall be ensured in enforcement proceedings. However, since the right to a fair trial was designed for the litigation in the court, a question arises as to the extent that the guarantees of the fair trial are extended to enforcement proceedings?

\section{The elements the right to a fair trial in enforcement proceedings}

Subsumed within the right to a fair trial are numerous procedural guarantees. These include the right to court access, the right to due process, the right to an independent and impartial court, the right to a public case hearing, and the right to a speedy case hearing, among others. Although Article 6 of the Convention was designed for the court trials (Harris, 2014: p. 395), since it also is applicable to enforcement proceedings this leads to the question to what extent the guarantees of this Article are applicable in enforcement proceedings?

The need and requirements of fair enforcement proceedings have been established in the Good Practice Guide on Enforcement of Judicial Decisions (hereinafter: the Guide) prepared by the European Commission for the Efficiency of Justice (CEPEJ $)^{10}$. The Guide recognized that without substantially undermining the right of creditors to obtain what is owed to them, the fundamental rights and interests of debtors also should be taken into account when implementing enforcement procedures. ${ }^{11}$ It also suggests that fair enforcement proceedings require encouraging debtors to be involved in enforcement procedures; protecting the right to privacy of debtors and their families; securing decent living conditions for debtors and their families; and punishing debtors' misconduct and offences. In addition to the requirements to protect certain debtor's rights, the Guide also reasonably links fair enforcement proceedings with the obligation of the debtor to refrain from wrongful actions (direct damage, concealment of assets and other illegal actions). Nevertheless, the Guide is a non-binding, soft law document which is only an

\footnotetext{
${ }^{10}$ European Commission for the Efficiency of Justice (CEPEJ) Good practice guide on enforcement of judicial decisions 10-11 December of 2015.

11 Ibid.
} 
important reflection of the existing legal practice. A concrete answer to the question to what extent the guarantees of the fair trial are applicable in enforcement proceedings is unclear. Thus, we discuss further what elements of the right to a fair trial are (or may be) applicable in enforcement proceedings.

\subsection{Reasonable length of enforcement proceedings}

Short duration is one of the main aspects of effective enforcement proceedings. If enforcement procedures are too drawn out, the effective defence of civil rights is illusionary and may even disappear. ${ }^{12}$ The ECHR has emphasized in various cases that the length of enforcement proceedings shall be reasonable. Of course, the court has not established any definite time limit for the conclusion of enforcement proceedings since this will vary from case to case. However, the goal of this practice is to encourage Member States to ensure that enforcement proceedings are conducted with due diligence.

Nevertheless, the requirement that enforcement proceedings be concluded within a reasonable length of time is strict, although reasonable delays can be justified in particular circumstances. Such cases could be failure of a creditor to comply with the requirements of enforcement proceedings and perform actions which are necessary for enforcement of a judgment. On the other hand, any delays in enforcement may not be so long as to impair the essence of the right protected under Article 6 of the Convention. ${ }^{13}$ A stay of execution of a judicial decision for such period as is strictly necessary to find a satisfactory solution to resolve public-order problems in the housing sector may be justified in exceptional circumstances. ${ }^{14} \mathrm{It}$ is worth noting that the length of enforcement proceedings impacts not only the creditor, but also a debtor. The obligation to reimburse enforcement proceedings costs usually falls upon the debtor. The costs associated with enforcement proceedings are usually directly proportional to the length of the proceedings, because the longer the enforcement process lasts, typically the more enforcement actions are taken in that process. Therefore, the length of enforcement proceedings is important for both parties - creditor and debtor.

\footnotetext{
${ }^{12}$ ECtHR 19.03.1997, Case Hornsby v. Greece, No. 18357/91.

${ }^{13}$ ECtHR 7.04.2005, Case UŽkureliene and others v. Lithuania, No. 62988/00, para. 31.

${ }^{14}$ ECtHR 19.03.1997, Case Hornsby v. Greece, No. 18357/91, para. 40; ECtHR 28/07.1999, Case Immobiliare Saffi v. Italy, No. 22774/93.
} 
In practice, execution of a judgment is often a complex procedure and the extent of its success often depends not only on the actions of the enforcement agent or (and) court, but also on participants involved in this procedure. The case law suggests that the length of enforcement proceedings is a function of various criteria, such as their complexity, the applicant's and competent authorities' behaviour and the amount and nature of the court award. ${ }^{15}$

A successful litigant may be required to undertake certain procedural steps in order to recover the judgment debt, either during a voluntary execution of a judgment or during its enforcement by compulsory means. ${ }^{16}$ Accordingly, it is not unreasonable that the authorities request the applicant to produce additional documents, such as bank details, to allow or expedite the execution of a judgment. ${ }^{17}$ Creditors are required to cooperate in the process. However, they should only be required to cooperate to the extent strictly necessary. It is for the Contracting States to organise their legal systems in such a way that the competent authorities can satisfy their obligations. ${ }^{18}$

In summary, Article 6 of the Convention requires enforcement proceedings to be carried out and concluded within a reasonable length of time and derogation from this requirement is permissible only in exceptional circumstances.

\subsection{Involvement of the parties in enforcement proceedings}

Cooperation between the parties is important in the court as well as in the enforcement stage. Enforcement proceedings are based on the active involvement of the parties, since in various cases in practice enforcement primarily depends on the active participation of the debtor. Also, the regulation of enforcement proceedings typically stipulates that the debtor should participate actively in enforcement proceedings rather than eluding the creditor and hiding property.

\footnotetext{
${ }^{15}$ ECtHR 23.09.2010, Case Vasilchenko v. Russia, No. 34784/02, para. 48; ECtHR 15.02.2007, Case Raylyan v. Russia, No. 22000/03, para. 31 .

${ }^{16}$ ECtHR 20.10.2005, Case Shvedov v. Russia, No. 69306/01, paras. 29-37.

${ }^{17}$ ECtHR 8.11.2007, Case Kosmidis and Kosmidou v. Greece, No. 32141/04, para. 24.

${ }^{18}$ ECtHR 6.04.2000, Case Comingersoll S.A. v. Portugal [GC], No. 35382/97, para. 24.
} 
The CEPEJ suggests that, so far as is possible and without slowing down enforcement procedures, Member States should encourage debtors to participate actively in enforcement procedures concerning them. For example, enforcement procedures can include time limits allowing for voluntary compliance with an enforcement title or friendly agreements on the sale of attached property. Moreover, so called "post-judicial mediation" should be available. ${ }^{19}$ Therefore, even though the parties may end the dispute by concluding a peaceful agreement in the court, the state should also allow conclusion of such agreement and/or voluntary enforcement of enforceable instrument even when the formal enforcement mechanism is carried out.

For instance, Article 655(1) of the Code of Civil Procedure of the Republic of Lithuania (thereinafter: CCP) establishes that a notice of enforcement shall mean a document, by which a bailiff notifies a debtor about the fact that an enforcement title has been served on him for execution and that if the actions referred to in this document are not accomplished within the term established by the bailiff, compulsory enforcement proceedings shall be begun. Pursuant to Article 659(1) of the CCP, if no term is established in the enforcement title, a bailiff shall set a term of ten days, calculating from the day the notice is served, for the debtor to satisfy the judgment. Furthermore, Article 595(1) of the CCP establishes that the judgment creditor and the debtor shall have the right to conclude a amicable agreement during enforcement proceedings. Therefore, the national legislation not only allows the parties to conclude an amicable agreement at any stage of enforcement proceedings, but also grants the right to the debtor to satisfy the judgment even when the bailiff begins the formal enforcement proceedings. Active involvement by the parties is closely linked with the requirement for fair enforcement proceedings since active and good faith participation by the parties leads to expeditious enforcement proceedings.

\footnotetext{
${ }^{19}$ European Commission for the Efficiency of Justice (CEPEJ) Good practice guide on enforcement of judicial decisions 10-11 December of 2015.
} 


\subsection{Equality of arms}

In practice, the principle of equality of arms has both positive and negative elements. In court proceedings, each party must be afforded a reasonable opportunity to present his case (positive element). Also, the parties cannot be placed at a substantial disadvantage vis-à-vis the other party (negative element). According to the case law of the ECHR, the principle of equality of arms and the right to an adversarial trial intertwine. ${ }^{20}$ On the one hand, both principles deal with the way arguments and evidence are presented before the court as well as the characteristics of the procedures before the court. On the other hand, the principle of adversary proceedings primarily relates to the procedures employed in court and how the decision is made. The principle of equality of arms relates more to the status of the parties and the balance of their procedural rights. However, the case law of the ECtHR does not establish how the principle of equality of arms shall be ensured in enforcement proceedings.

The authors believe that the principle of equality of the parties is a particularly important element in enforcement proceedings as well. Even though in the enforcement proceedings the legal dispute between the parties is over, meaning that the winning party (the creditor) is determined, consideration of the fair position of the debtor during these proceedings is equally important. Also, since the ECHR regards enforcement proceedings as a continuation of the trial in the court, there is no argument to refuse to apply one of the fundamental principles of civil proceedings in the latter stage of enforcement.

\subsection{Adversarial proceedings}

The concept of a fair trial comprises the fundamental right to adversarial proceedings. This is closely linked to the principle of equality of arms. ${ }^{21}$ The need to save time and expedite the proceedings does not justify disregarding such a fundamental principle as the right to adversarial proceedings. ${ }^{22}$ Though the principle of adversarial proceedings is primarily designed for litigation in the court, it may be applicable in enforcement proceedings according to the peculiarities of these

\footnotetext{
${ }^{20}$ ECtHR 19.10.2005, Case Makhfi v. France, No. 59335/00.

${ }^{21}$ ECtHR 19.09.2017, Case Regner v. The Czech Republic, No. 35289/11, para. 146.

22 ECtHR 18.02.1997, Case Nideröst-Huber v. Switzerland, No. 18990/91, para. 30.
} 
proceedings. For instance, the adversarial principle is reflected in the legal norms establishing the right of the parties to appeal against the actions of the bailiff when the parties argue that the bailiff breached their rights during enforcement proceedings (Višinskis, 1999, 18). Also, often when the parties claim violation of their rights in enforcement proceedings, they have the burden to prove it. One of the examples are claims for the invalid sale of property in enforcement proceedings. For instance, a debtor may argue that the property was sold for unreasonably low price or the procedure of a public auction was unlawful. In such case the applicant has to prove that his or her fundamental rights were violated. ${ }^{23}$ However, the question is how best this principle should be applied when the parties to the enforcement proceedings submit their claims to the enforcement agent and not to the court. What evidence can the enforcement agent demand the applicant to submit? How should the obligation of onus probandi apply in such case?

The adversarial principle is also important in addressing the issue of the financial evaluation of the seized property. For example, if the applicant claims that the seized property was improperly valued in violation of the procedures and that its price was therefore incorrect at the time of the auction, the applicant shall provide information that the price determined by the bailiff was significantly lower than the market price. ${ }^{24}$ In practice, the application of adversarial proceedings contributes to the lawfulness of enforcement proceedings and discourages the parties from submitting frivolous claims which may impede effective enforcement proceedings.

Also, another aspect of adversarial proceedings is that the parties have a right to have their dispute heard publicly. The ECHR has found that in proceedings before a court of first and only instance, the right to a "public hearing" within the meaning of Article 6 (1) of the Convention entails an entitlement to an "oral hearing" unless there are exceptional circumstances that justify dispensing with such a bearing $\langle\ldots>$. In proceedings before two instances, at least one instance must, in general, provide such a bearing if no such exceptional circumstances are at hand. ${ }^{25}$ Nevertheless, in practice the application of this rule in enforcement proceedings is not always followed. For instance, according to Article 442 (6) and 443(5) of the CCP, claims against enforcement agents are usually settled in written proceedings by the court in Lithuania. Although the law gives the right to the court to organize oral

\footnotetext{
${ }^{23}$ Court of Appeal of Lithuania 12.12.2019, case No. e2A-1280-798/2019.

${ }^{24}$ Court of Appeal of Lithuania 12/12/2019, case No. 2A-422-464/2018.

${ }^{25}$ ECtHR 13.03.2018, Case Mirovni Inštitut v. Slovenia, No. 32303/13.
} 
hearings in such cases, this right is not often used. Thus, the question arises whether in cases when the plaintiff disputes actions of the enforcement agents, considering the importance of such disputes, hearing the case only upon written submission is compatible with Article 6 of the Convention.

\section{The liability for unfair enforcement proceedings}

If the guarantees of Article 6 of the Convention are at least to some extent applicable in enforcement proceedings, the question then arises who shall ensure the right to fair enforcement proceedings? In various Contracting States the court is only a passive supervisor of enforcement proceedings but does not actively manage enforcement. Rather, the court only settles any disputes that arise during the enforcement stage. In practice, it falls to the enforcement agent (bailiff) to ensure the proceedings are carried out fairly. On the one hand, all Contracting States of the Convention must ensure the rights and freedoms provided for under the Convention within their jurisdictions. ${ }^{26}$ This would suggest that irrespective of which model is chosen, a Contracting State must ensure the right to a fair enforcement procedure. On the other hand, the Contracting States shall be responsible only for the actions which are attributable to it.

The ECHR has extended the right to a fair trial to situations in which the enforcement of judicial decisions is directed by private persons. ${ }^{27}$ The Court has found that whether they work as private professionals or they are employed by the state, enforcement agents are vested with a measure of public authority when performing their task of enforcing enforceable titles and act as "public State body". ${ }^{28}$ In the further case law the ECHR noted the state has a positive obligation to organise a system for enforcement of judgments that is effective both in law and in practice and that ensures their enforcement without any undue delay. In other words, the Contracting States shall not only adopt necessary regulations, but also, if necessary, provide measures which mandate effective enforcement proceedings. Consequently, the Contracting States shall be liable for acts or omissions of enforcement agents, if they breach Article 6 of the Convention. ${ }^{29}$ Moreover, the Court has established that

\footnotetext{
${ }^{26}$ Article 1 of the Convention.

${ }^{27}$ ECtHR 11.01.2001, Case Lunari v. Italy, No. 21463/93.

${ }^{28}$ European Commission For the Efficiency of Justice, "Good practice guide on enforcement of judicial decisions", 2015; ECtHR 11.01.2001, Case Platakou v. Greece, No. 38460/97.

${ }^{29}$ ECtHR 7.06.2005, Case Fuklev v. Ukraine, No. 71186/01, para. 84.
} 
the burden to ensure compliance with a judgment against the state lies primarily with the state authorities starting from the date on which the judgment becomes binding and enforceable. ${ }^{30}$

However, the Court has held that the right of access to a court does not oblige a state to execute every single civil judgment, no matter what the judgment or the circumstances. ${ }^{31}$ Exceptions to liability of the state can be found, for example, when the judgment creditor fails to take actions. ${ }^{32}$ Also, authorities are provided some degree of discretion in situations where enforcement could disturb the public order or where rights of others are involved. Some authors suggest that, pursuant to the case law of the ECHR, the right to enforcement does not entail an absolute right to obtain what was awarded in the judgment and in such disputes the ECHR reviews whether the authorities acted adequately and sufficiently (Hazelhorst, 2017: p. 160161).

The relevant case law suggests that state authorities are primarily responsible for ensuring effective enforcement proceedings. This also suggests that this duty must be carried out by the state irrespective of which enforcement system is established in the national law. Consequently, the breach of this duty may lead to liability on the part of the responsible Contracting State under Article 6 of the Convention.

In principle, to date the ECHR has only considered the liability of the state for the delays in enforcement proceedings. Nevertheless, in some exceptional circumstances, the state may not have liability, for instance, if the enforcement depends solely on the actions of certain persons and no coercive measures are undertaken to ensure enforcement.

\footnotetext{
${ }^{30}$ ECtHR 1.03.2016, Case Arbačiauskienè v. Lithuania, No. 2971/08, para. 86.

${ }^{31}$ ECtHR 19.02.2014, Case García Mateos v. Spain, No. 38285/09, para. 42.

${ }^{32}$ ECtHR 7.06.2005, Case Fuklev v. Ukraine, No. 71186/01.
} 


\section{The application of Article 6 of the Convention to enforcement of arbitral awards}

The application of Article 6 of the Convention to enforcement proceedings is based on the presumption that if the state court has rendered a judgment, the state also should ensure that such judgment is executed. However, should the same reasoning be followed in the enforcement of arbitral award rendered by the arbitration court? Unfortunately, this significant question has not been addressed thoroughly in the legal literature so far or by the courts.

Arbitration is a private dispute resolution mechanism and no (limited) involvement of the state is required (Jokubauskas et al., 2020: p. 12). Since the basis of commercial arbitration as a rule is a contract between the parties, they are also obliged to respect and execute arbitral awards (pacta sunt servanda). The private nature of commercial arbitration suggests that since the parties decided to curb jurisdiction of the state courts and limit recourse through the arbitration court, they should also carry the burden of the execution of arbitral awards. The arbitral tribunals, while having the competence to render awards which have the same force and binding nature as judgments rendered by the state courts, lack the competence and mechanisms to enforce their awards. Thus, the nature of arbitration, as a private dispute resolution mechanism, suggests that the parties to an arbitration agreement refuse any involvement of state coercive measures in enforcement of arbitral awards. This means that, if the losing party fails to execute the arbitral award, the winning party is rendered defenceless and could only claim for the violation of the arbitration agreement in the court. Why should the state allow the application of coercive measure for the enforcement of the decision which has been rendered by a private institution (commercial arbitration court), when there are essentially no clear requirements for the arbitral awards in the law and where state courts often are vested with very limited jurisdiction to ensure the validity of the arbitral award?

The ECHR has established that some elements of the right to a fair trial are also applicable in arbitration (for instance, impartiality of the tribunal). ${ }^{33}$ Nevertheless, the Court has not yet addressed whether Article 6 of the Convention is also applicable when the arbitral award has to be enforced. One may argue that since an

${ }^{33}$ ECtHR 1.03.2016, Case Tabbane v. Switzerland, No. 41069/12. 
arbitration tribunal has a legal obligation/duty to ensure the right to a fair trial to some extent, this right should be also expanded to the enforcement proceedings and that the Contracting States must ensure that the rights set forth in Article 6 of the Convention are given effect irrespective of the source of that judgment (arbitral award or court judgment) that has to be enforced. But this argument is weak since the conclusion of an arbitration agreement is a waiver of the guarantees of Article 6 of the Convention (Jokubauskas et al., 2020: p. 45-46). This reasoning suggests that since the parties waived their right to a fair trial, they also waived the right to fair enforcement proceedings. In other words, the losing party may legitimately argue that the state coercive measures should not be applicable because the parties deliberately refused to enjoy the state litigation system by concluding an arbitration agreement which voluntarily and knowingly constituted a waiver of the rights to a fair trial as enshrined in Article 6 of the Convention.

On the other hand, one can argue that arbitrations are largely useless if there are no mechanisms to enforce arbitral awards. This logic explains why States adopt legislation that permits parties to arbitration agreements to rely on state coercive measures for the enforcement of arbitral awards. For instance, Article 41(1) of the Law on Commercial Arbitration of the Republic of Lithuania establishes that the award of the arbitral tribunal shall take effect upon its adoption and shall be enforceable by the parties. Article 41(4) of this law establishes that the award of the arbitral tribunal is an enforceable document, enforceable from its entry into force in accordance with the procedure established by the CCP. If the award of the arbitral tribunal located in the Republic of Lithuania is not enforced, the district court of the place of arbitration shall issue a writ of execution at the request of the party in accordance with the procedure established by the CCP. An application for an enforcement order shall be dealt with by written procedure.

Similar approaches can be found in other states. Article 1055 of the Code of Civil Procedure of Germany, for example, establishes that amongst the parties, the arbitration award has the same effect as that of a final and binding judgment handed down by the court. Also, coercive enforcement of an arbitral award is regarded as a compulsory enforcement measure when the court has declared an arbitration award as enforceable (Article 1060(1) of Zivilprozessordnung). The court decides a petition for compulsory enforcement of an arbitration award by a court order. Prior to the decision, the opponent must be heard (Article 1063(1) of Zivilprozessordnung). 
According to Article 2(1) of the Code of Enforcement Procedure of the Republic of Estonia, "obligations arising from the following enforcement instruments shall be fulfilled: ... (6) a decision of an arbitral tribunal permanently operating in Estonia, as well as a decision of another arbitral tribunal declared enforceable". Thus, in Estonia the procedure for the enforcement of arbitral awards is based on the submission to the court for a declaration of enforceability of an arbitral award and the decision of the state court to declare the arbitral award enforceable.

Another practical issue pertains to the actual enforcement of arbitral awards. The enforcement system is primarily designed for enforcement of court judgments. For instance, according to Article 646(1) of the CCP, after an executory judgment becomes res judicata, the court of first instance shall issue a writ of execution to the judgment creditor pursuant to a written application. In essence, the writ of execution is literally incorporated from the resolution part of the court's judgment which must be particularly clear and explicit. Article 270(5)(1) of the CCP establishes that the resolution part of the judgment shall contain the conclusion of the court to grant the claim and/or counter-claim in full or in part, at the same time setting forth the contents of the allowed claim, or to dismiss the claim and/or counterclaim. This requires the enforcement agent to act strictly in accordance with the resolution part of the judgment.

However, the problem is that there are no analogous requirements for the enforcement of arbitral awards. Given the popularity of arbitration, this is a glaring omission. The arbitral award may only decide that the applicant's claim is satisfied or the arbitration tribunal may only require the respondent to perform a contract. These very limited resolution components of the arbitral award lead to complicated, practical problems in the enforcement proceedings. Since the state courts have no competence to modify arbitral awards, they should only incorporate the resolution part of arbitral awards into the writ of execution. Consequently, the enforcement agent will encounter the problem concerning how the arbitral award shall be enforced if, for instance, the losing party refuses to act in situations where the award obliges the losing party to perform certain actions instead of adjudging the losing party to pay a concrete sum of money to the winning party. 
Therefore, the application of Article 6 of the Convention to the enforcement of arbitral awards is debatable. This problem derives not only from the doubts whether the Contracting States are obliged to ensure fair enforcement of arbitral awards, but also from the practical problems regarding the actual enforcement actions of such decisions. The authors do not offer any firm recommendations regarding the effective enforcement of arbitral awards, but do strongly recommend that the substantial problems surrounding this receive more attention both in practice and academia since arbitration is becoming ever more popular and since the utility of arbitration will be diminished if the gaps that currently exist in enforcement mechanisms are allowed to exist.

\section{Conclusions}

1) The position of enforcement proceedings in the system of law is debatable. Nevertheless, the requirement for the continuation of legal defence in the court and after litigation suggests that the same level of protection of human rights shall be ensured in enforcement proceedings. Thus, the right to a fair trial under Article 6 of the Convention is also applicable to enforcement proceedings.

2) Most of the elements of the right to a fair trial shall be applicable to enforcement proceedings. The authors suggest that in enforcement proceedings the rights to reasonable length of proceedings, the involvement of the parties in the proceedings, equality of arms, and adversarial proceedings are all applicable. However, there are peculiarities in the application of these principles since in many cases they have to be applied by the enforcement agent and not the court.

3) Regardless of the position of enforcement agents (bailiffs) (private, state or mixed position) the state is liable for the violation of Article 6 of the Convention in enforcement proceedings. However, this liability may be reduced or eliminated depending to the nature of the specific enforcement proceedings.

4) Application of Article 6 of the Convention to the enforcement of arbitral awards raises both practical and theoretical dilemmas. Since the arbitration agreement constitute a waiver of the guarantees of Article 6 of the Convention, one may also claim that it constitutes a waiver of state assistance in enforcement proceedings as well. Also, the actual 
enforcement of arbitral awards may be hindered since enforcement systems are designed for enforcement of court judgments and not arbitral awards.

\section{References}

Harris, D. J., O'Boyle, M. (2014) Law of the European Convention on Human Rights (Oxford University Press).

Hazelhorst, M. (2017) Free Movement of Civil Judgments in the European Union and the Right to a Fair Trial (Springer, the Netherlands).

Jokubauskas, R., Kirkutis, M., Tamošiūnienè, E., Višinskis, V. (2020) Ginčų nagrinèjimas komerciniame arbitraže, (Mykolas Romeris University, Lithuania).

Kerameus, K. D. (1997) Enforcement in The International Context (Martinus Nijhoff Publishes, the Netherlands).

Lautenbach, G. (2013) The Concept of the Rule of Law and the European Court of Human Rights (Oxford: University Press).

Stauskiené, E. (2007) Teisinè vykdymo proceso prigimtis, Jurisprudencija 1(91) (Mykolas Romeris University).

Višinskis, V. (1999) Teismo sprendimų vykdymo procesinès problemos daktaro disertacija (Mykolas Romeris University, Lithuania).

Валеев, А Х. (2008) Исполнительное производство (Publisher Издательский дом “Питер”).

\section{About the authors}

Dalia Višinskyte is a Ph.D. candidate at Mykolas Romeris University in Vilnius, Lithuania; the Graduate of the Institute Geneva and University of Geneva (joint MIDS programme) (Switzerland), e-mail: dalia.visinskyte@mids.ch.

Mykolas Kirkutis is a Ph.D. candidate at Mykolas Romeris University in Vilnius, Lithuania, e-mail: mkirkutis@gmail.com.

Remigijus Jokubauskas is a Ph.D researcher at Mykolas Romeris University in Vilnius, Lithuania and a consultant of the Council of Europe; e-mail: remigijus@jokubauskas.org.

Prof. dr. Vigintas Višinskis is a professor at Mykolas Romeris University in Vilnius, Lithuania and a judge at the Court of Appeal of Lithuania, e-mail: vigvis@gmail.com. 